\title{
Changes in macroinvertebrate community and biotic indices associated with streamflow regulation and wastewater inputs in Sierra Cebollera Natural Park (La Rioja, Northern Spain)
}

\author{
Rubén Ladrera* and Narcís Prat \\ Departament d'Ecologia, Universitat de Barcelona, Diagonal 645, 08028 Barcelona \\ * Corresponding author: rubenladreraf@ hotmail.com
}

Received: 8/3/13

Accepted: 22/8/13

\begin{abstract}
Changes in macroinvertebrate community and biotic indices associated with streamflow regulation and wastewater inputs in Sierra Cebollera Natural Park (La Rioja, Northern Spain)

The macroinvertebrate communities of two mountain streams in the Sierra Cebollera Natural Park (La Rioja, Northern Spain) were studied to ascertain the changes in these communities and their ecological status, considering the two main pressures that exist in the area, i.e., the Pajares Reservoir and various wastewater discharges. While the alterations in the macroinvertebrate communities were minimal downstream of the wastewater discharges, significant changes were detected in the composition of the community in the stream reaches located downstream of the Pajares Reservoir. This major disturbance downstream of the dam was especially intense in those reaches affected by a massive growth of the invasive algae Didymosphenia geminata, which might be related to dam operation. Despite a small decrease in the different biotic indices used, especially IBMWP and IMMi-T, downstream of the Pajares Reservoir, no large changes in the biological quality levels were detected (from high to good conditions). We conclude that the biotic indices did not completely reflect the changes produced by the disturbances present in the studied streams, especially the effects produced by the presence of a large dam. This study highlights the importance of considering measures other than the biotic indices to study the ecological status of headwater streams and rivers using macroinvertebrates, such as multivariate analysis, when the main disturbance is the alteration of the physical habitat rather than organic pollution.
\end{abstract}

Key words: Mountain streams, macroinvertebrates, biotic indices, reservoir, Didymosphenia geminata, wastewater discharges.

\section{RESUMEN}

Cambios en la comunidad de macroinvertebrados y en los índices biológicos asociados con la regulación hidrológica y las entradas de aguas residuales en el Parque Natural Sierra Cebollera (La Rioja, Norte de España)

Se ha llevado a cabo un estudio de las comunidades de macroinvertebrados acuáticos de los principales cursos fluviales del Parque Natural Sierra Cebollera (La Rioja, Norte de España) con el objetivo de conocer el cambio en dichas comunidades y en su estado ecológico a lo largo de los dos ríos estudiados, teniendo en cuenta las diferentes presiones de origen antrópico existentes en la zona de estudio, fundamentalmente la presencia del embalse de Pajares y diferentes vertidos de aguas residuales. Aguas abajo de los vertidos de aguas residuales la alteración de la comunidad de macroinvertebrados fue mínima, mientras que los principales cambios se detectaron en los tramos fluviales localizados aguas abajo del embalse de Pajares. Esta mayor alteración aguas abajo del embalse resultó especialmente intensa en aquellos tramos afectados por un crecimiento masivo del alga invasora Didymosphenia geminata, el cual podría estar relacionado con las condiciones generadas por el embalse. A pesar de pequeños descensos en los diferentes índices bióticos utilizados, especialmente en el IBMWP y en el IMMi-T aguas abajo del embalse de Pajares, no se detectaron grandes cambios en los niveles de calidad biológica (pasando de muy buena a buena). Por lo tanto, los índices bióticos no reflejaron completamente los cambios producidos por las presiones existentes en los ríos estudiados, especialmente aquellos producidos por el embalse. Este estudio pone de manifiesto la importancia de tomar en consideración otros análisis más allá de los índices bióticos, cómo el análisis multivariante, para estudiar el estado ecológico de los ríos de cabecera mediante la comunidad de macroinvertebrados cuando los niveles de contaminación orgánica son bajos y las presiones afectan fundamentalmente a variables físicas del hábitat.

Palabras clave: Ríos de cabecera, macroinvertebrados, índices bióticos, embalse, Didymosphenia geminata, vertidos urbanos. 


\section{INTRODUCTION}

The assessment of the ecological status of rivers and streams is essential for the sustainable management of these ecosystems. The European Water Framework Directive (WFD) has established the need to use biotic indices to assess the ecological status of rivers, and the most widely used indices are those based on the macroinvertebrate community (Ector \& Rimet, 2005; Bonada et al., 2006; Birk et al., 2012). Numerous biotic indices based on the macroinvertebrate community have been developed and widely used in recent years (Munné \& Prat, 2009), such as the IASPT (Armitage et al., 1983) and the IBMWP (Alba-Tercedor et al., 2002) for the Iberian Peninsula. However, these biotic indices are based on a single metric, while the WFD recommends the use of multimetric indices based on a combination of different metrics to establish the ecological status of water bodies (Heiskanen et al., 2004; Birk et al., 2012). Different multimetric indices have thus been proposed in Europe that are based on qualitative or quantitative data, as IMMi-L and IMMi-T, respectively, both defined specifically for Spanish Mediterranean rivers (Munné \& Prat, 2009).

Methods for analyzing the macroinvertebrate community using multivariate approaches (e.g., CCA, FCA, MDS) have also commonly been used to study the effects of different anthropogenic pressures on river ecosystems (Rieradevall et al., 1999; Vivas et al,. 2002; Gerhardt et al., 2004; Castillo et al., 2006; Hrodey et al., 2008). These analyses are often particularly sensitive to subtle changes in the community structure (Castillo et al. 2006) that cannot be detected with biological indices, so they may also be used to establish the biological condition of fluvial ecosystems (Rieradevall et al., 1999). In the present study, we have analyzed the structure of the invertebrate community and calculated different biotic indices along the streams of a mountainous area, Sierra Cebollera Natural Park (La Rioja, Northern Spain), where dam and wastewater discharges are the principal anthropogenic pressures on the aquatic ecosystem. The main objective of our study is to understand the effects of such disturbances on the macroinvertebrate community.

Wastewater discharge is an important disturbance that can cause changes in macroinvertebrate communities. Treated or untreated sewage typically causes an increase in the amount of organic matter and nutrients in the river, leading to an increase in microbial activity (Gulis \& Suberkropp, 2003) and causing a decline in water oxygen concentration (Rueda et al., 2002). An increase in organic matter also alters the energetic relations of the river, thus disrupting the community (Dyer et al., 2003; Gücker et al., 2006). Several studies have shown how macroinvertebrate communities change in areas that are affected by wastewater discharges (Ortiz \& Puig, 2007; Spänhoff et al., 2007; Grantham et al., 2012); however, the impact of wastewater discharges on the river depends on various factors such as the ratio between river flow and sewage volume (Gücker et al., 2006).

Another important factor that affects the composition of macroinvertebrate communities is the presence of reservoirs. According to Bunn \& Arthington (2002), the main factors affecting communities in regulated rivers are i) alterations in the physical properties of the rivers, ii) changes in the hydrological regime, iii) a loss of longitudinal and lateral connectivity, and iv) the invasion and success of exotic species that are favored by the altered flow regime. Recently published studies have proposed management strategies aiming to reduce impacts on regulated rivers (Richter et al., 2006; Poff et al., 2010). However, the effects of a dam on the river biota also depend on factors such as reservoir size, basin characteristics and the hydrological regime generated by the dam (Horsák et al., 2009).

The specific objectives of the present study are i) to characterize the longitudinal evolution of the macroinvertebrate communities in the two main mountain streams (Iregua and Lumbreras Streams) of the Sierra Cebollera Natural Park (La Rioja, Northern Spain) and ii) to study the alterations associated with the disturbances present on the macroinvertebrate community structure and the ecological status of these streams. One of the streams (Lumbreras) is regulated by the 
Pajares Reservoir, and both streams receive wastewater discharges from small villages. We hypothesize that, in the studied streams, i) the main alteration of the macroinvertebrate community is related to the presence of the Pajares Reservoir and is mainly associated with the important hydrological regulation exerted by the dam, ii) the alteration of the macroinvertebrate community composition associated with the wastewater discharges is related to the magnitude of sewage discharge with respect to the streamflow, and iii) the decline of biotic indices reflects the changes produced both by the reservoir alteration and the water sewage inputs according to the intensity of such disturbances. Reservoir regulation is hypothesized to have a greater impact on the extent of the changes in the macroinvertebrate communities than is sewage input.

\section{METHODOLOGY}

\section{Study area and sampling strategy}

The study was performed along two mountain streams in the Sierra Cebollera Natural Park (La Rioja, Northern Spain; Fig. 1): the Iregua Stream (order 1-4), which represents the main channel, and its tributary, the Lumbreras Stream (order 2-3). The Pajares Reservoir, constructed in 1995 with a capacity of $35 \mathrm{hm}^{3}$, is located in the Lumbreras Stream and is primarily used for water storage from September to June and water is released during the irrigation period, mainly in July and August. This hydrological regulation completely alters the natural hydrograph in the river reaches downstream of the reservoir (Fig. 2). The natural flow regimes of the studied streams are

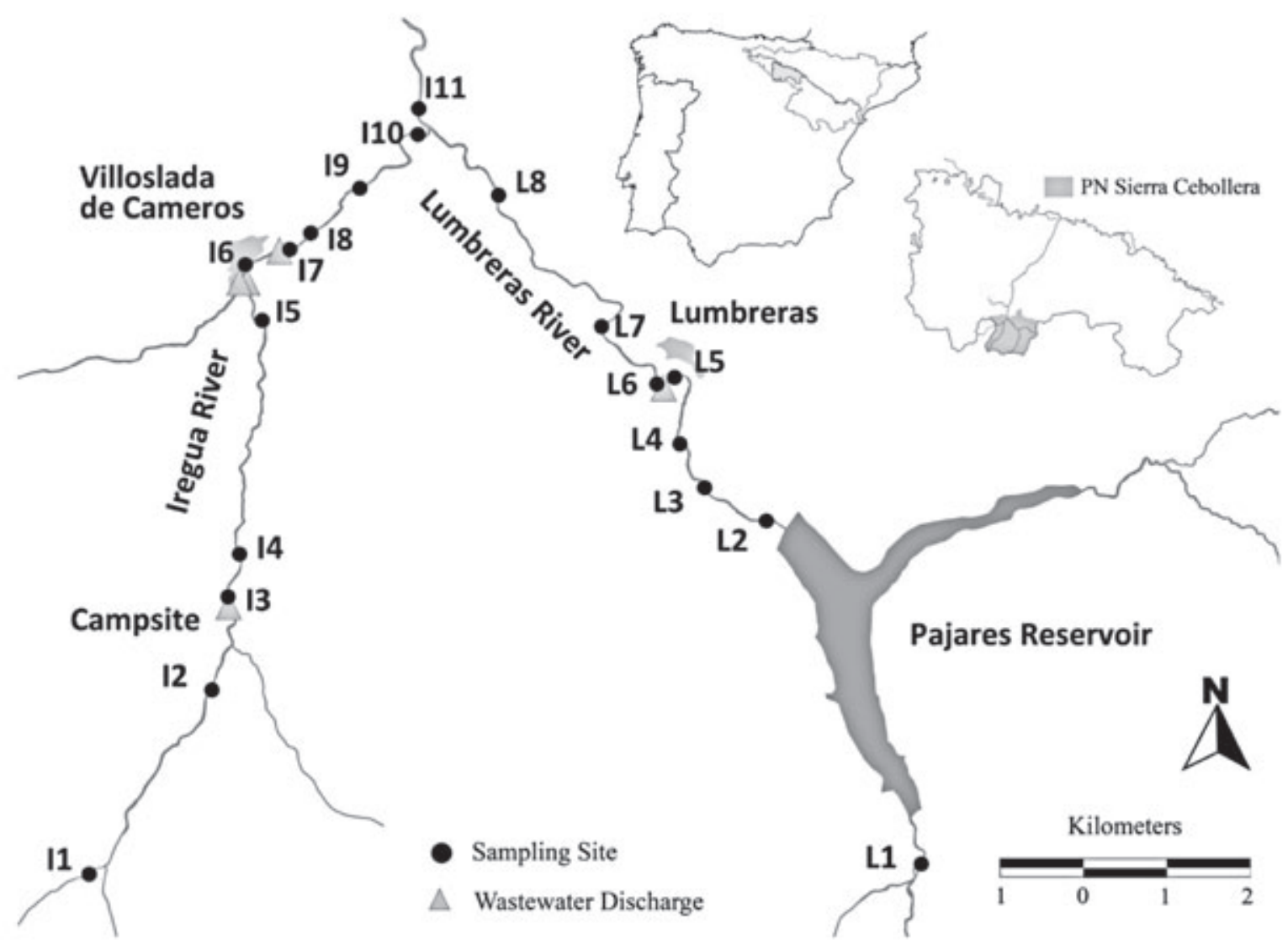

Figure 1. Sampling sites in the study area. Puntos de muestreo en la zona de estudio. 


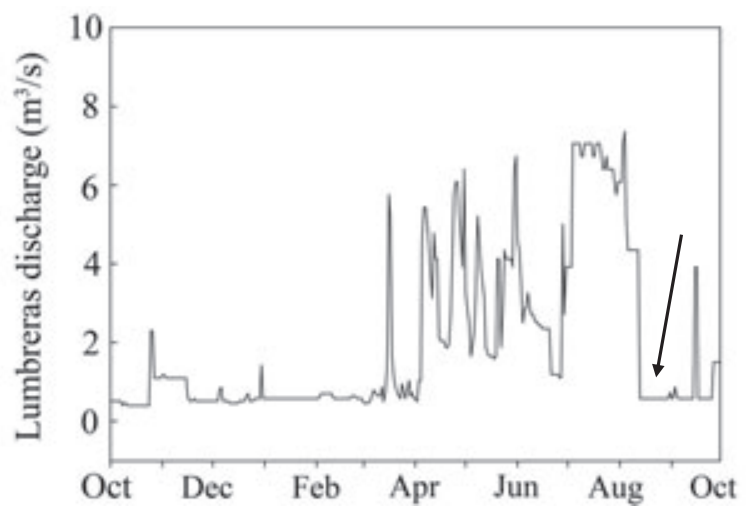

Figure 2. Discharge in the Lumbreras Stream downstream of the Pajares Reservoir for the period 2010-2011. The arrow shows the sampling period. Hidrograma del río Lumbreras aguas abajo del embalse de Pajares para el periodo 2010-2011. Se indica con una flecha el momento del muestreo.

higher in the spring, when thawing and maximum spring rainfalls occur; however, due to river regulation, the maximum base flows occur during the summer for the stream reaches downstream of the dam (Fig. 2).

There are different wastewater discharges due to the presence of several villages and campsites in the study area (Fig. 1). In the Iregua Stream, there are two untreated discharge sources and one treated discharge source (the sewage plant) from the Villoslada de Cameros Village (362 inhabitants, INE 2010), together with another untreated discharge source from a campsite located $3 \mathrm{~km}$ upstream of this village. In the Lumbreras Stream, the untreated sewage water from Lumbreras Village (164 inhabitants, INE 2010) is discharged $2.5 \mathrm{~km}$ downstream of the Pajares Dam (Fig. 1).

A total of 19 stream reaches were studied in the described area; 11 in the Iregua Stream and 8 in the Lumbreras Stream, with at least one sample situated upstream and another downstream of each pressure described. We took samples in late August 2011 to characterize the ecological status of the watercourses. At that time of year the watercourses should be more sensitive to the described pressures because of the greater population density and the lower streamflow. Moreover, this time also coincides with the cessation of high flow rates downstream of the reservoir associated to the irrigation period.

\section{Measured environmental variables}

Thirty-two environmental variables belonging to different categories (physico-chemical, hydromorphological and biological variables; Table 1) were studied for each site. The hydrological regime was considered as a qualitative variable in the statistical analysis, so the studied sites were grouped into two sets. The first set included the sample sites located downstream of the $\mathrm{Pa}$ jares Dam (L2-L8 and I11), with the hydrological regimen directly affected by this reservoir. These sites experienced a very high flow up to 5 days prior to the sampling date during the summer, 10 times higher than at sampling time (Fig. 2). The second group included sites that were not affected by the Pajares Dam (L1 and I1-I10). The hydrological regimen of these sites was natural, with similar discharges as those observed during the weeks preceding the sampling date. Because large amounts of the invasive alga Didymosphenia geminata were present during sampling, its biomass was considered to be a possible factor of community composition disruption; it was, thus, included as another environmental variable in the analysis. The D. geminata biomass was calculated as dry weight (DW) of algal material per stream bed area $\left(\mathrm{g} / \mathrm{m}^{2}\right)$. We used the algal mats accumulated into the 8 surber nets used for macroinvertebrate sampling in dominant substrates. After sorting all macroinvertebrates, the filaments of D. geminata were dried for $72 \mathrm{~h}$ at $70{ }^{\circ} \mathrm{C}$ and weighted for DW determination.

\section{Macroinvertebrate sampling and Biotic Indices}

Multi-habitat samples for the analysis of the macroinvertebrate community were collected using a 250- $\mu \mathrm{m}$ surber net, according to the MIQU sampling protocol, which was designed by the FEM research group of the University of Barcelona. This protocol considers the presence of 12 different habitat types: bryophytes, algae, submerged hydrophytes, emerged spermatophytes, submerged roots, coarse organic matter, natural uniform surfaces, boulders, cobbles, pebbles, fine sediments and sand and lime. It 
Table 1. Environmental variables studied in each site, categories and codes used in the present study. Variables ambientales estudiadas en cada punto de muestreo, categorías y acrónimos utilizado en el presente estudio.

\begin{tabular}{|c|c|c|c|}
\hline Categories & Description & Code & Methodology \\
\hline $\begin{array}{l}\text { Physico-chemical } \\
\text { variables }\end{array}$ & 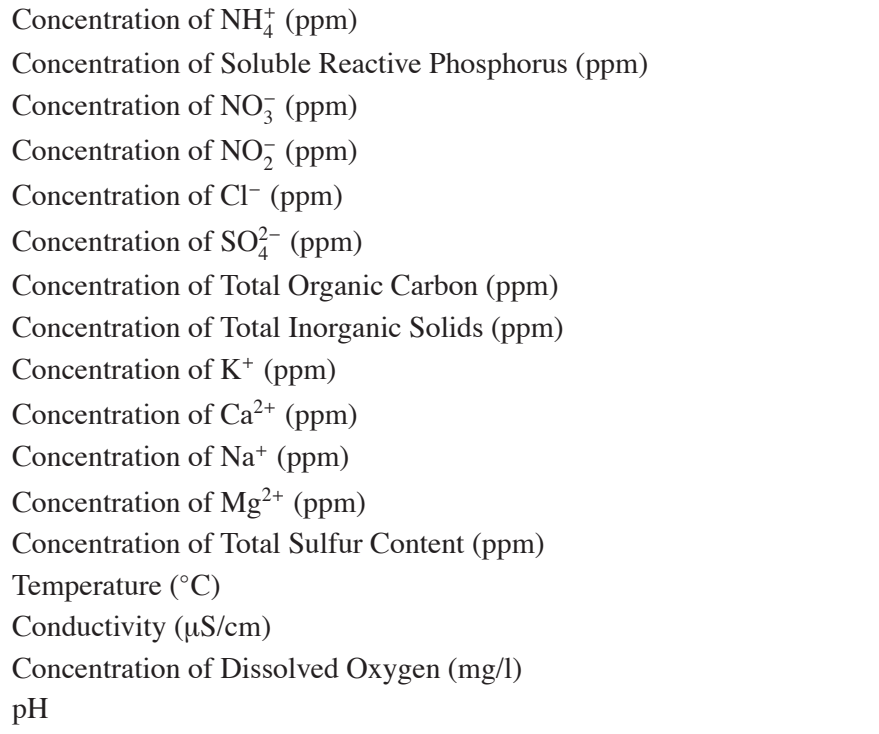 & $\begin{array}{l}\mathrm{NH} 4 \\
\mathrm{SRP}-\mathrm{PO} 4 \\
\mathrm{NO} 3 \\
\mathrm{NO} 2 \\
\mathrm{Cl} \\
\mathrm{SO} 4 \\
\mathrm{TOC} \\
\mathrm{TIS} \\
\mathrm{K} \\
\mathrm{Ca} \\
\mathrm{Na} \\
\mathrm{Mg} \\
\mathrm{S} \\
\mathrm{T} \\
\mathrm{Cond} \\
\mathrm{DO} \\
\mathrm{pH}\end{array}$ & (ASTM 1995) \\
\hline $\begin{array}{l}\text { Hydromorphological } \\
\text { variables }\end{array}$ & $\begin{array}{l}\text { Component of QBR referring to total riparian vegetation cover } \\
\text { Component of QBR referring to vegetation cover structure } \\
\text { Component of QBR referring to cover quality } \\
\text { Component of QBR referring to river channel alteration } \\
\text { Total score of the Riparian Forest Quality Index } \\
\text { Component of IHF referring to embeddedness in riffles and runs } \\
\text { Component of IHF referring to riffle frequency } \\
\text { Component of IHF referring to substrate composition } \\
\text { Component of IHF referring to velocity/depth regime } \\
\text { Component of IHF referring to shading of river bed } \\
\text { Component of IHF referring to heterogeneity components } \\
\text { Component of IHF referring to aquatic vegetation cover } \\
\text { Total score of the Habitat Fluvial Index } \\
\text { Hydrological regimen. Affected or not by the hydrological regulation of } \\
\text { the Pajares dam. }\end{array}$ & $\begin{array}{l}\text { QBR-cover } \\
\text { QBR-struc } \\
\text { QBR-quali } \\
\text { QBR-natur } \\
\text { QBR } \\
\text { IHF-embed } \\
\text { IHF-riffle } \\
\text { IHF-subst } \\
\text { IHF-veloc } \\
\text { IHF-shade } \\
\text { IHF-heter } \\
\text { IHF-veget } \\
\text { IHF } \\
\text { Hidrology }\end{array}$ & $\begin{array}{l}\text { (Munné et al., 2003) } \\
\text { (Pardo et al., 2002) } \\
\text { This paper }\end{array}$ \\
\hline Biological variables & Dry weight of Didymosphenia geminata $\left(\mathrm{gDW} / \mathrm{m}^{2}\right)$ & Didymo & This paper \\
\hline
\end{tabular}

distinguishes dominant and marginal habitats, depending on whether they occur in more or less than $5 \%$ of the river reach surface, respectively. Eight surber samples were taken in dominant substrates, and 4 samples were taken in marginal substrates, according to the relative importance of each substrate. The material was stored in two different samples, one for dominant substrates and the other for marginal substrates. The samples were combined to obtain the biotic indices.
The material was preserved in $4 \%$ formaldehyde and taken to the laboratory to be identified. The identification of macroinvertebrates was generally made to the family level, except for Oligochaeta, Hydracharina and Ostracoda. If necessary, sub-sampling was conducted to estimate the taxa abundances, and at least 300 individuals per sample were identified and counted (for a further description of the protocol see Nuñez \& Prat, 2010). 
Different biotic indices (Table 2) were calculated using the MAQBIR software (Munné, 2009). According to WFD and to compare results from various indices, the indices were standardized by calculating the EQR value (Ecological Quality Ratio), i.e., dividing the value of each index by the reference value for the "Mediterranean Siliceous Mountain" river type, according to the official classification of these rivers by the Spanish Water Authorities (MMARM, 2008).

\section{Data analysis}

A Principal Coordinate Analysis (PCoA) was performed to establish the similarities between the macroinvertebrate communities of the different sampling sites (PERMANOVA + for PRIMER; Anderson et al., 2008). To characterize the influence of the different environmental variables on the distribution of sampling sites in the PCoA analysis, a Spearman correlation analysis was conducted on the first two axes of the PCoA with the environmental variables transformed using $\ln (x+1)$. Two groups of sampling sites were differentiated on the PCoA graph based on a hierarchical cluster analysis (unweighted pair group method using arithmetic averages, UPGMA; software R2.14.0, package vegan 2.0-3, Oksanen et al., 2012). To confirm whether the two major cluster groups were significantly different in terms of the macroinvertebrate community, a one-way ANOSIM (Analysis of similarities; Clarke, 1993) was performed (PERMANOVA + for PRIMER). The
ANOSIM, PCoA and cluster analysis methods were elaborated from the Chord distance matrix (Ordoci, 1967) based on the macroinvertebrate abundance transformed using $\ln (x+1)$.

The IndVal method (Dufrêne \& Legendre, 1997) was applied to determine the indicator community of each group that was defined in the cluster analysis. This method provides the indicator value (IV-value) for each taxon in each group according to its presence and abundance in any case. The IV-value is scaled from 0 to 100 , with a value of 100 indicating that a taxon was collected in every sample within a group and not in the other group. A Monte Carlo permutation test with 9999 permutations was used to test the significance of each IV-value. To visualize the distributions of those taxa that featured significantly in the IndVal analysis and had an IV-value higher than 89 for either group, we created bubble graphs of these taxa. Bubble graphs, an option on the PRIMER package, display the relative abundance of each taxon in each sampling site and are plotted on the PCoA graph.

Considering the differences between the two previously established groups, the groups were separately studied further to determine the similarities among the sites in each group and the environmental variables responsible for the groups' biological structures. For each group, distance-base linear models (DISTLM analysis; PERMANOVA + for PRIMER) were run to investigate the relationship between the macroinvertebrate community and the environmental variables. The macroinvertebrate distance

Table 2. Biotic quality indices analyzed. Índices bióticos calculados.

\begin{tabular}{lcc}
\hline Biotic Indices & Acronym & Reference/Source \\
\hline $\begin{array}{l}\text { Unimetric indices } \\
\text { Based on qualitative data } \\
\text { Iberian Average Score per Taxon } \\
\text { Iberian Biological Monitoring Working Party }\end{array}$ & IASPT & Jáimez-Cuéllar et al. (2002) \\
IBMWP & Alba-Tercedor et al. (2002) \\
\hline $\begin{array}{l}\text { Multimetric indices } \\
\text { Based on qualitative data } \\
\text { Intercalibration Common Multimetric Index 11a }\end{array}$ & INMi-L & (Munné \& Prat, 2009) \\
Base on quantitative data & IMMi-T & (Munné \& Prat, 2009) \\
\hline
\end{tabular}


matrices were created using the Chord distance method after the macroinvertebrate data were transformed using $\ln (x+1)$. The environmental variables were transformed using $\ln (x+1)$ and normalized. The variables that were highly correlated were removed from the analysis. The DISTLM routine was based on the forward selection procedure and two different selection criterion, AIC (Akaike, 1973) and $R^{2}$ (Sokal \& Rohlf, 1981), to obtain the environmental variables that accounted for more variation. For each group, a dbRDA plot from the DISTLM analysis based on the $R^{2}$ selection criterion was used to visualize the final model using the CANOCO 4.5 software (Ter Braak \& Smilauer, 2002). In each dbRDA plot, we show those environmental variables that were selected in the final model obtained from the DISTLM analysis and the taxa with the highest Spearman correlation coefficient with the two axes of the plot.

\section{RESULTS}

\section{Environmental variables}

Among the various environmental variables considered (Table 3 ), it should be noted a slight increase in the conductivity (from 73 to $170 \mu \mathrm{S}$ / $\mathrm{cm}$ ) and concentration of SRP-PO4 (from 0.012 to $0.204 \mathrm{ppm}$ ) along the longitudinal profile of the Iregua Stream, especially downstream from Villoslada de Cameros (I6), coincident with the wastewater discharges observed in this village (Fig. 1). The temperature at the sites located downstream of the Pajares Reservoir (L2-L8 and I11) ranged between 9.9 and $15.2^{\circ} \mathrm{C}$, while the temperature of the sites that were not affected by this reservoir (L1 and I1-I10) ranged between $16^{\circ} \mathrm{C}$ and $22^{\circ} \mathrm{C}$.

The stream reaches located downstream of the Pajares Reservoir also experienced a decrease in the IHF index due to the reduction of values in different components of this index, such as the substrate composition and the velocity regimen. However, the main component affected in the IHF index downstream of the Pajares Reservoir was component 7 , which refers to instream vegetation (Table 1). The alteration of instream vegetation was especially intense in the reaches located from the reservoir to Lumbreras Village (L2-L5). This alteration appeared to be related to the massive growth (up to $3.5 \mathrm{mg} / \mathrm{m}^{2}$ ) of the invasive alga $D$. geminata in these reaches, which affected $2.3 \mathrm{~km}$ of the Lumbreras Stream, covering almost all available benthic substrates. The massive growth of $D$. geminata disappeared downstream of the wastewater discharge coming from Lumbreras Village (L6), which caused a seven-fold increase in the concentration of SRP-PO4 (from 0.014 to $0.099 \mathrm{ppm}$ ). Apart from this chemical compound, the wastewater discharge caused minor or no changes in the other analyzed components (e.g., conductivity changes from 71 to $72 \mu \mathrm{S} / \mathrm{cm}$ ).

In the case of Iregua Stream, the smallest value of IHF was detected at site I6, located in Villoslada de Cameros Village, where the river is channelized. This situation also negatively affected the riparian forest and provoked a decrease of the QBR index at sample sites I6 and $I 7$ (the latter, which are located immediately downstream of this village, at a lower intensity). However, the lowest QBR index value in the study area was detected at site L2, which is located 200 m downstream of the Pajares Reservoir, where the vegetation was completely absent and the stream was channelized over $400 \mathrm{~m}$ of its length, which also affected the low IHF index at site L2.

\section{Macroinvertebrate community}

The hierarchical cluster analysis (Fig. 3) based on the macroinvertebrate community grouped sites into two major groups, one corresponding to the reaches affected by the dam regulation (L2-L8 and I11) and the other to non-regulated sites of the studied streams (L1 and I1-I10). The ANOSIM analysis confirmed significant differences between the macroinvertebrate communities of the two established groups $(R=0.847$, $p=0.01)$. These two major groups were clearly separated along the first axis of the PCoA analysis (Fig. 4), which explained $40.1 \%$ of the total variance. The hydrological regulation and temperature were the environmental variables 


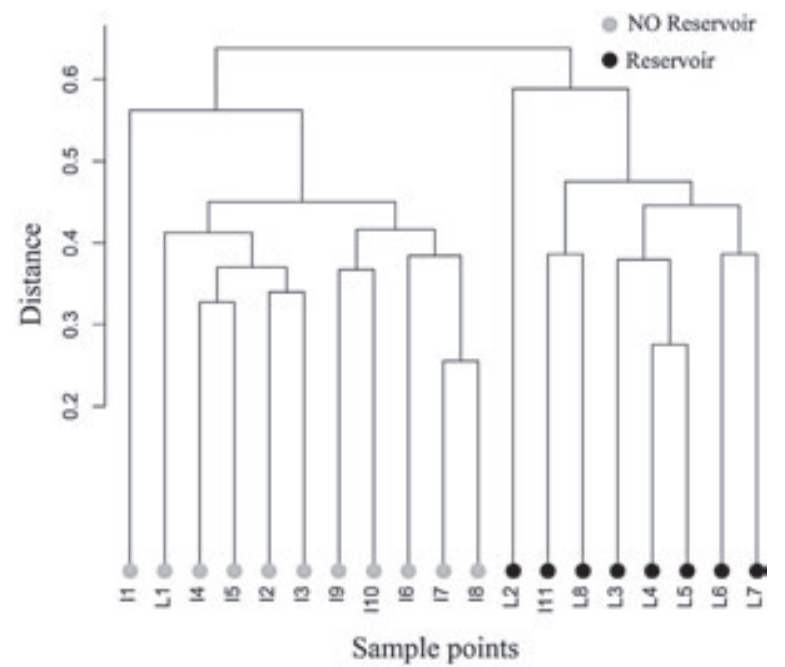

Figure 3. Hierarchical cluster analysis (UPGMA) based on macroinvertebrate community. Reservoir refers to those sites located downstream of the Pajares Reservoir. Análisis clúster jerárquico (UPGMA) basado en la comunidad de macroinvertebrados. "Reservoir" se refiere a los puntos de muestreo localizados aguas abajo del embalse de Pajares.

that showed the highest correlation with this first axis of the PCoA graph (Spearman correlation coefficients $=0.86$ and -0.85 , respectively).

The IndVal analysis indicated 20 taxa as significant indicators for the group of sites that were not affected by the Pajares Reservoir and only four taxa for the other group. Among the taxa with the highest IV-value (Fig. 4), those indicative of the group of sites that were not affected by the Pajares Reservoir were the families Brachycentridae, Goeridae and, especially, Gerridae, Caenidae and Corixidae, which did not appear in any of the sites downstream of the dam (on the right side of the PCoA graph). The family Ephemerellidae showed the highest IV-value for the group of sites located downstream of the Pajares Reservoir.

The DISTLM analysis between the macroinvertebrate community and the environmental variables of the sites affected by the Pajares Reservoir (L2-L8 and I11) resulted in a final model showing $D$. geminata biomass as the unique predictor variable $(\mathrm{AIC}=-17.74$; Pseudo-F $=3.54 ; p=0.0026)$. Five environmental variables were selected in the final model accounting for $94.7 \%$ of the total variance (dbRDA using $\mathrm{R}^{2}$ as its selection criterion; Fig. 5). However, the unique significant variable in the distribution of the sampling sites was shown to be the $D$. geminata biomass $\left(R^{2}=0.37\right.$; Pseudo-F $=3.54 ; p=0.0032)$. Therefore, according to the selection criteria AIC and $R^{2}$, the D. gemi-

Table 3. Values of the environmental variables that showed the highest differences among the studied sites. Valores de las variables ambientales que presentaron mayores diferencias entre los puntos de estudio.

\begin{tabular}{|c|c|c|c|c|c|c|c|c|}
\hline Site & $\begin{array}{l}\text { Streamflow } \\
\text { regulation }\end{array}$ & $\mathrm{T}^{\mathrm{a}}\left({ }^{\circ} \mathrm{C}\right)$ & $\begin{array}{l}\text { Conductivity } \\
(\mu \mathrm{S} / \mathrm{cm})\end{array}$ & SRP-PO4 (ppm) & QBR & IHF-veget & IHF & $\begin{array}{l}\text { D. geminata } \\
\left(\mathrm{g} \mathrm{DW} / \mathrm{m}^{2}\right)\end{array}$ \\
\hline I1 & No & 17.1 & 76 & 0.014 & 85 & 15 & 78 & 0.00 \\
\hline $\mathrm{I} 2$ & No & 22.4 & 73 & 0.012 & 45 & 20 & 74 & 0.00 \\
\hline $\mathrm{I} 3$ & No & 21.8 & 81 & 0.076 & 95 & 15 & 75 & 0.00 \\
\hline I4 & No & 22.1 & 82 & 0.025 & 80 & 15 & 70 & 0.00 \\
\hline I5 & No & 16.2 & 100 & 0.016 & 85 & 15 & 75 & 0.00 \\
\hline I6 & No & 17.7 & 152 & 0.151 & 20 & 10 & 61 & 0.00 \\
\hline I7 & No & 21.7 & 158 & 0.142 & 40 & 10 & 70 & 0.00 \\
\hline I8 & No & 22.1 & 161 & 0.204 & 80 & 10 & 70 & 0.00 \\
\hline I9 & No & 20.2 & 169 & 0.157 & 100 & 10 & 73 & 0.00 \\
\hline $\mathrm{I} 10$ & No & 20.6 & 170 & 0.105 & 85 & 20 & 80 & 0.00 \\
\hline I11 & Yes & 15.2 & 86 & 0.066 & 50 & 15 & 76 & 0.00 \\
\hline L1 & No & 20.7 & 67 & 0.026 & 80 & 10 & 65 & 0.00 \\
\hline L2 & Yes & 9.9 & 68 & 0.002 & 5 & 5 & 54 & 22.04 \\
\hline L3 & Yes & 10.7 & 71 & 0.011 & 100 & 5 & 61 & 3.59 \\
\hline $\mathrm{L} 4$ & Yes & 11.9 & 71 & 0.005 & 100 & 5 & 63 & 6.26 \\
\hline L5 & Yes & 11.9 & 71 & 0.014 & 70 & 5 & 63 & 6.36 \\
\hline L6 & Yes & 9.5 & 72 & 0.099 & 100 & 10 & 66 & 0.42 \\
\hline L7 & Yes & 13.9 & 71 & 0.036 & 75 & 15 & 78 & 0.11 \\
\hline L8 & Yes & 13.9 & 70 & 0.019 & 100 & 15 & 76 & 0.00 \\
\hline
\end{tabular}


nata biomass appeared to be the main environmental variable responsible for the community differences among sites in this group. The $D$. geminata biomass resulted especially correlated with the first axis of the analysis, and those sites affected by the massive growth of this alga
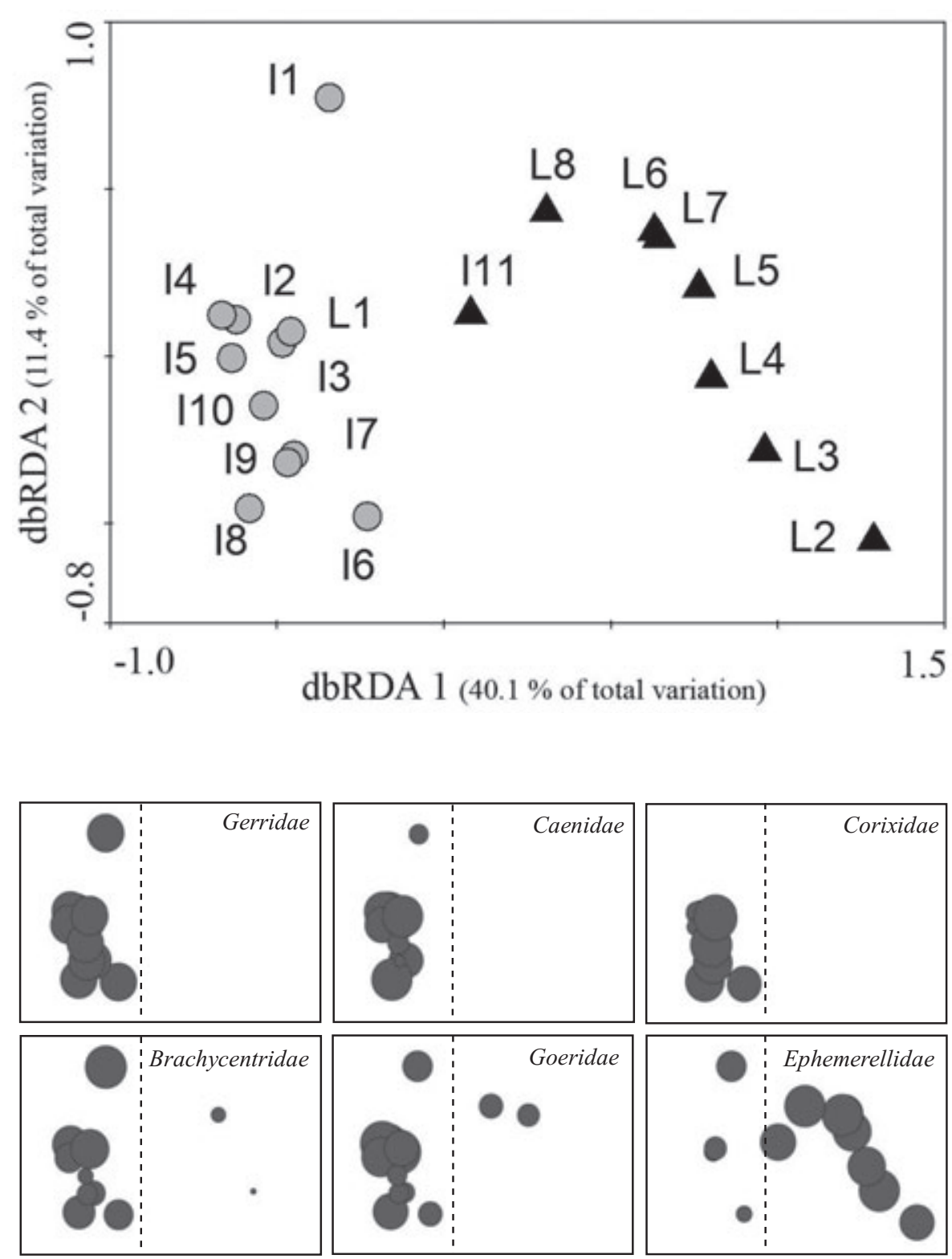

Figure 4. (Upper) Principal Coordinate Analysis (PCoA) based on macroinvertebrate community. Different symbols group sample sites according to the hierarchical cluster analysis (UPGMA) elaborated. (Lower) Bubble graphs plotted on the PCoA graph and proportional to the abundance of each taxon that was significant in the IndVal analysis for any of the previously determined groups and that had an IV-value higher than 0.89 in the analysis.(Arriba) Análisis de Coordenadas Principales (ACoP) basado en la comunidad de macroinvertebrados. Se señalan con diferentes símbolos los puntos de muestreo de los dos grupos principales de acuerdo al análisis de clúster jerárquico (UPGMA) realizado. (Abajo) Gráficos de burbujas representado sobre el gráfico PCoA y proporcionales a la abundancia de los taxones de macroinvertebrados que resultaron significativos en el análisis IndVal para alguno de los dos grupos previamente establecidos y que presentaron un valor indicador superior a 0.89 en este análisis. 
appeared on the right part of the plot (Fig. 5). The families Simuliidae and Heptageniidae had the highest correlation coefficients with this axis, ( $R^{2}$ values of -0.93 and -0.87 , respectively). Among the regulated sites that were not affected by the massive growth of D. geminata, sites L6 and L7 (located $100 \mathrm{~m}$ and $1 \mathrm{~km}$ downstream of the sewage discharge coming from Lumbreras Village, respectively) showed minor differences in their macroinvertebrate compositions in comparison to sites located downstream the sewage input (L8 and I11). In any case, these differences appeared in the second axis of the analysis, which represents only $15.8 \%$ of the total variance.

The DISTLM analysis between the macroinvertebrate community and the environmental variables of the sites that were not affected by the Pajares Reservoir (L1 and I1-I10), using the AIC as the selection criterion, resulted in a final model with conductivity as the unique predictor variable $(\mathrm{AIC}=-24.98 ;$ Pseudo-F $=2.78$; $p=0.002)$. Nine environmental variables were selected in the final model, which accounted for the $94.7 \%$ of the total variance (dbRDA using $R^{2}$ as its selection criterion; Fig. 6). However, the unique significant variable in the distribution of the sampling sites appeared to be the conductivity $\left(R^{2}=0.24\right.$; Pseudo-F $\left.=2.78 ; p=0.007\right)$. Sampling sites I1 and L1, appeared on the right part of the plot. Some differences were observed among the other sites of the Iregua Stream located upstream (I2-I5) or downstream (I6-I10) of Villoslada de Cameros; these differences were related to different components of the QBR index and/or to nutrient concentrations and conductivity. The taxa that showed the highest correlation with either of the first two axes of the analysis were the family Psychomyiidae $(r=0.9)$, associated with sites located in or downstream of Villoslada de Cameros (I6-I10), and the family Perlidae $(r=-0.9)$, with higher densities upstream of this village.

\section{Biotic Indices}

Figure 7 shows the evolution of the various biotic indices along the two studied streams. With regard to the unimetric indices (IASPT and IBMWP), we did not observe notable differences among the study sites in the IASPT index.

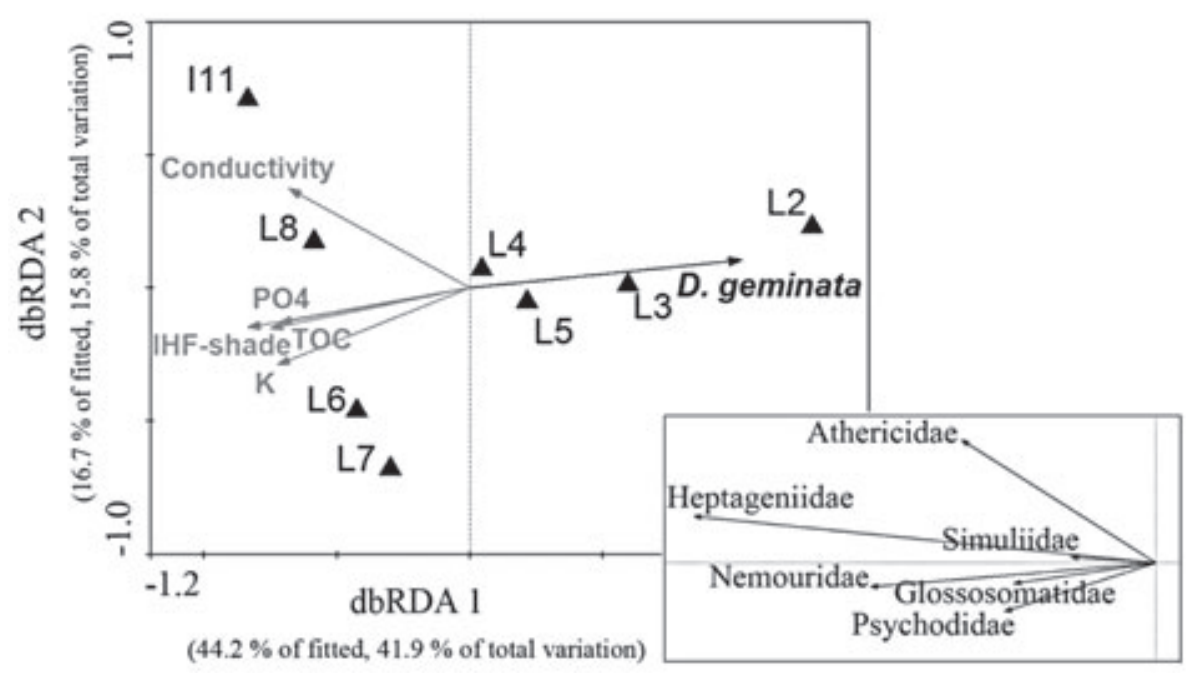

Figure 5. dbRDA plot results from the DISTLM analysis for the sample sites that were affected by Pajares Reservoir, using $R^{2}$ as selection criterion. Significant $(p<0.05)$ variables in the final model have been highlighted. On the bottom-right corner appear the invertebrate taxa that have a Spearman correlation coefficient higher than 0.75 with the first axis. dbRDA resultante del análisis DISTLM para los puntos de muestreo afectados por el embalse de Pajares usando la $\mathrm{R}^{2}$ como criterio de selección de variables. Se resaltan aquellas variables ambientales que resultaron significativas ( $\mathrm{p}<0.05)$ en el modelo final. En la esquina inferior derecha se muestran los taxones que presentaron un coeficiente de correlación de Spearman superior a 0.75 con el eje 1. 
However, for IBMWP, the sites affected by the dam and the massive growth of $D$. geminata showed lower values in general, especially site L2, located $200 \mathrm{~m}$ downstream of the Pajares Reservoir, which was the site most affected by the massive growth of $D$. geminata.

The multimetric indices (IMMi-L and IMMiT) also failed to detect important differences among sampling sites, especially the qualitative index IMMi-L, while the quantitative index IMMi-T showed an evolution similar to that observed for the IBMWP index, with particularly low values at site L2. The ecological status of the studied sites never fell below the "good" category according to the limits proposed by Munné \& Prat (2009). Among the sites that were not affected by the streamflow regulation, no differences in any of the studied indices were detected, and all values for these sites were always in the "high" category.

\section{DISCUSSION}

\section{The importance of streamflow regulation}

The macroinvertebrate community of sites located downstream of the Pajares Reservoir was found to be substantially altered, which is a similar result to those obtained in previous studies conducted in regulated rivers (Munn \& Brusven, 1991; Jakob et al., 2003; Bruno et al., 2010) and in accordance with our hypothesis 1 . These changes were mainly correlated to the proximity of the Pajares Reservoir which could exert its effects through the regulation of the hydrological and temperature regime.

The taxa most negatively affected by the proximity of the Pajares Reservoir were the families Gerridae, Corixidae and Caenidae (Fig. 4), all of which might be particularly sensitive to the high flows and current speeds generated by the dam preceding the sampling date. These families are adapted to lentic regimes (Tachet et al., 2006), and Caenidae is particularly sensitive to disturbances in bed sediment (Poff et al., 2006). In the case of Corixidae, its life cycle is completely aquatic, which increases its sensitiv- ity to episodes of great flow (Lytle \& Poff 2004; Shafroth et al., 2010). All organisms of this family that were present in the study area belong to the genus Micronecta, which has a very small size, so they are more easily dragged by high flows. The sensitivity of smaller-bodied taxa organisms to high flow episodes observed is consistent with other studies (Mérigoux \& Dolédec, 2004) and has been associated with different anatomical or behavioral strategies that allow large-bodied taxa (with stronger attachment structures) to withstand high hydraulic stress.

Water temperature seemed to be also altered by the presence of the Pajares Reservoir and might be also responsible for some changes on macroinvertebrate community composition. In our streams, the changes in the density of the family Ephemerellidae must be noted, with high densities observed downstream of the Pajares Reservoir, though it was only present in four sites that were not affected by the reservoir and always at much lower densities. According to other studies (Arnekleiv, 1985; Perry et al., 1986; Svensson, 2001), the higher larval densities of this family downstream of the dam may be related to the delay of adult emergence in these reaches as a result of the lower temperatures. These lower temperatures are related to the water released from the hypolimnion of the reservoir. The delay in the emergence of aquatic insect larvae has been frequently described in rivers in temperate regions that are regulated by hypolimnetic dams (Prat, 1981; Ward \& Stanford, 1982).

Important differences were observed among the macroinvertebrate communities of the sites located downstream of the Pajares Reservoir, though they are all located within a short span of the stream $(6 \mathrm{~km})$ and have similar flow regimes and temperatures. According to the DISTLM analysis, the unique significant environmental variable accounting for such differences in the macroinvertebrate communities among these sites was the biomass of D. geminata.

D. geminata is a stalk-forming freshwater diatom that has historically been found in cold and oligotrophic lakes and streams of North America and Northern Europe, but it has recently become an invasive species in many lotic sys- 
tems worldwide, including the Iberian Peninsula (Blanco \& Ector, 2009). In the present study, we detected a massive growth of this diatom downstream of the Pajares Reservoir. This massive growth might be favored downstream of the reservoir due to the combination of a stable flow environment, lower temperatures and low phosphorous content, which are the main factors that allow this diatom to develop massive growths (Kirkwood et al., 2007, 2009; Kumar et al., 2009; Kilroy \& Bothwell, 2012). In this sense, D. geminata has been observed to persist preferentially in stable channels and in more regulated flow regimes, such as stretches that are downstream of lakes and reservoirs (Kirkwood et al., 2009). The massive growth was especially intense at site L2, although it was found to cover almost the entire substrate until the wastewater discharge from Lumbreras Village, in the study sites L2 to L5. The disappearance of the massive algal growth after the sewage discharge could be related to the increase of inorganic phosphate in the stream in this point, as indicated in other studies that have stressed the importance of low phosphorous content in the water for the massive algal growth (Ellwood \& Whitton, 2007; Miller et al., 2009; Kilroy \& Bothwell, 2012). It is interesting to note that despite the relatively low importance of the discharge from Lumbreras Village, its effects on the macroinvertebrate

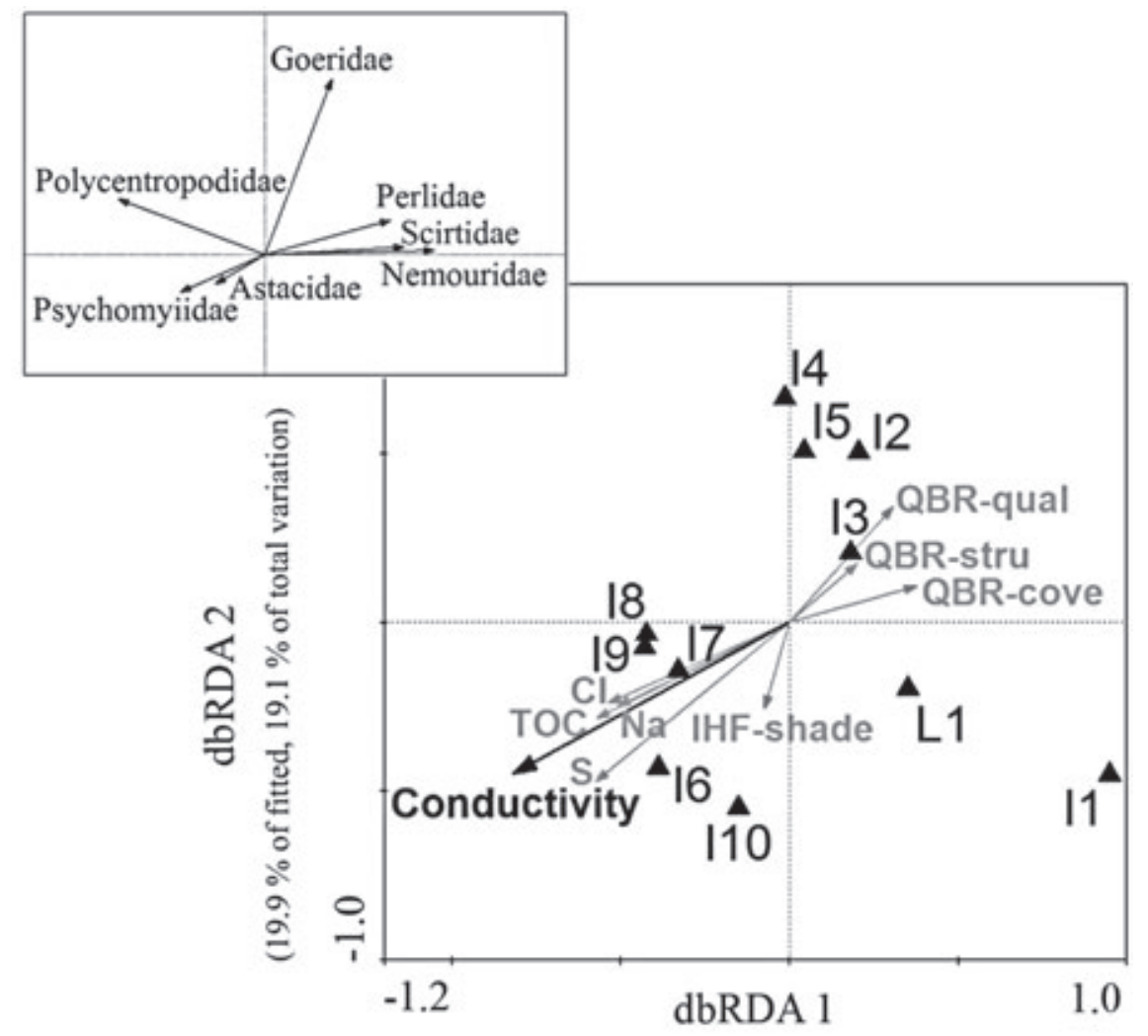

( $29.5 \%$ of fitted, $29.3 \%$ of total variation)

Figure 6. dbRDA plot results from the DISTLM analysis for the sample sites that were not affected by Pajares Reservoir, using $R^{2}$ as selection criterion. Significant $(p<0.05)$ variables in the final model have been highlighted. On the top-left corner appear the invertebrate taxa that have a Spearman correlation coefficient higher than 0.7 with some of the first two axis. dbRDA resultante del análisis DISTLM para los puntos de muestreo no afectados por el embalse de Pajares usando la $\mathrm{R}^{2}$ como criterio de selección de variables. Se resaltan aquellas variables ambientales que resultaron significativas $(\mathrm{p}<0.05)$ en el modelo final. En la esquina superior izquierda se muestran los taxones que presentaron un coeficiente de correlación de Spearman superior a 0.7 con alguno de los dos primeros ejes. 
communities is important because the increase in phosphorous decreases the algal biomass. The important effects of this alga on the benthic communities of fluvial ecosystems has been frequently addressed (Kilroy et al., 2009; Gillis $\&$ Chalifour, 2010). This intense alteration of the community has been associated with the total cover of the riverbed by the algal filaments
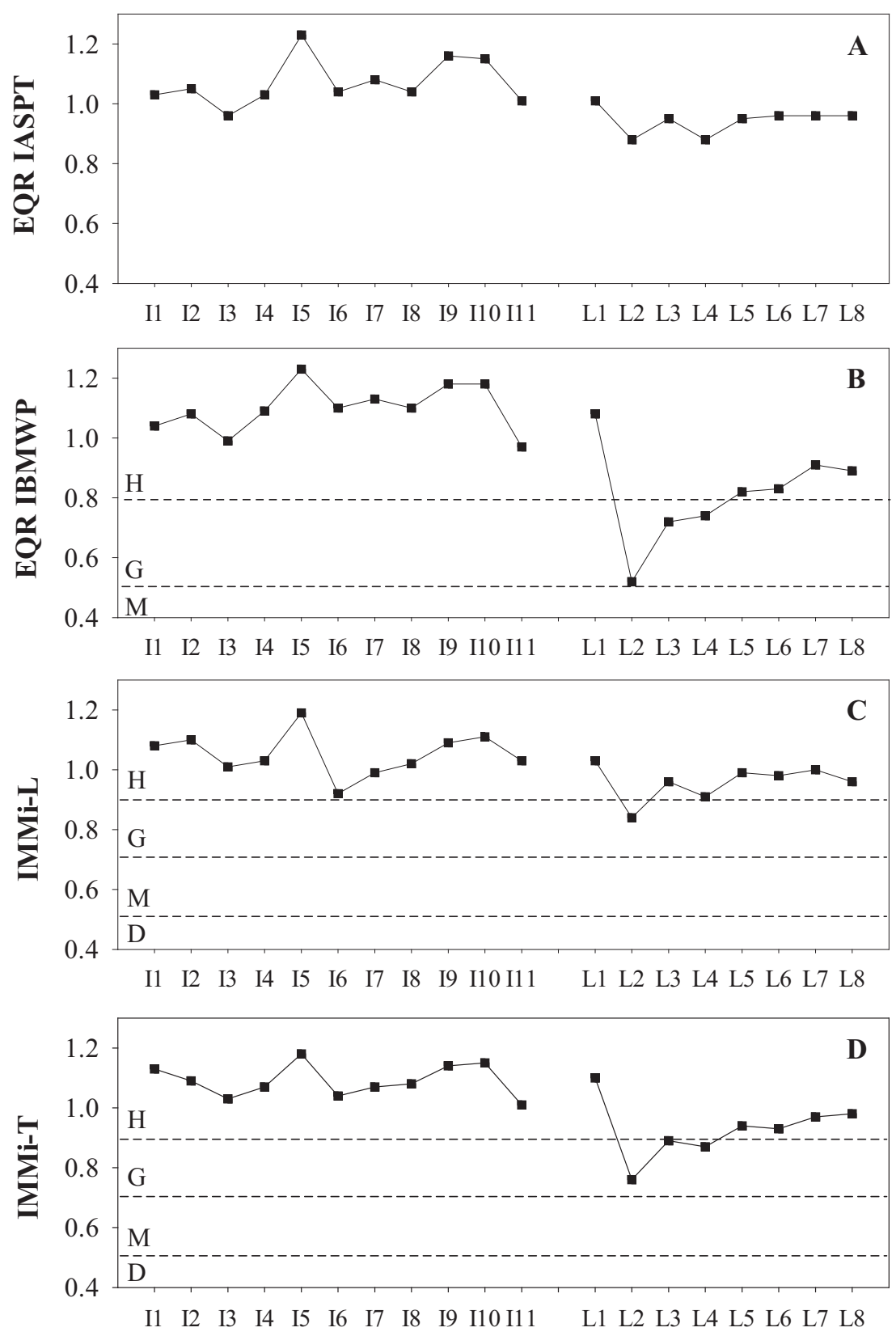

Figure 7. Values of the biotic indices analyzed. Discontinued lines show the quality class boundaries (EQR values) according to Munné \& Prat (2009). H means "high", G "good”, M "moderate" and D "deficient". Valores de los diferentes índices bióticos calculados. Se marcan con líneas discontinuas los valores límite para la inclusión de una masa de agua en las diferentes clases de calidad (Munné \& Prat, 2009). H indica “alto”, G “bueno”, M “moderado” y D “deficiente”. 
(Larson, 2007). In this sense, in the present study, the most severely affected taxa at sites with massive growths of $D$. geminata were the family Simuliidae, which could be related to the loss of a suitable stable substrate for attachment, and the family Heptageniidae, which could be due to the impossibility of moving freely in areas covered by mats of $D$. geminata. Both taxa were more abundant downstream of the sewage input than they were upstream of this input.

\section{The importance of wastewater discharges}

The correlation of wastewater discharges with the macroinvertebrate community of the study appears to depend on the flow of the receiving streams, according to Gücker et al.(2006). In this sense, and in agreement with different authors (Ortiz \& Puig, 2007; Spänhoff et al., 2007; Grantham et al., 2012), we observed an alteration of the macroinvertebrate community in the Iregua Stream from Villoslada de Cameros (I6) that was associated with an increase of different chemical compounds and conductivity, which was the unique significant environmental variable in the DISTLM analysis. The increase in conductivity and of chemical compounds as SRP-PO4 occurred downstream of the sewage discharges coming from Villoslada de Cameros, which were especially significant in the summer. At that time, the minimum streamflows occur and the population density is higher in the area. In the Lumbreras Stream, we also observed some disturbance in the community downstream of the wastewater discharge from Lumbreras Village (L6), although this disturbance was minimal. The most important effect in this case was the change in the biomass of D. geminata, as previously discussed. This varying responses to wastewater inputs could be related to the higher flow of the Lumbreras Stream with respect to Iregua Stream in Villoslada de Cameros $\left(0.6\right.$ and $0.3 \mathrm{~m}^{3} / \mathrm{s}$, respectively) and to the very high flows of the Lumbreras Stream during the weeks preceding the sampling date (approximately $7 \mathrm{~m}^{3} / \mathrm{s} ;$ Fig. 2).

In the Iregua Stream (which had lower flows), we observed a certain succession of taxa along the longitudinal profile of the stream that was particularly associated with wastewater discharges. However, it must be noted that there was physical degradation of the stream habitat in and immediately downstream of Villoslada de Cameros (including sites I6 and I7), thus reducing the QBR and IHF indices, which could also affect the biological community. According to the DISTLM analysis, the main environmental variables responsible for the community alteration were various chemical compounds and, especially, the conductivity. In this sense, taxa that require better water quality, such as the family Perlidae, appeared to be associated with sites located upstream of Villoslada de Cameros (I1-I5), while sites located downstream of this village showed higher densities of Psychomyiidae, which seems to be favored by a greater growth of plant material as a consequence of the higher concentration of nutrients in the stream (Puig, 1999). In any case, changes in the macroinvertebrate community associated with wastewater discharges were slight, as expected. We did not measure the wastewater discharges flows, but they were lower than $20 \mathrm{l} / \mathrm{s}$, which means that the dilution from stream water (300 1/s) was enough to reduce the effects of wastewater discharges on the community.

\section{The relevance of Biotic Indices in headwater streams}

The alteration of the macroinvertebrate community previously described in areas affected by the dam resulted in a slight generalized decrease of the calculated biotic indices, except for the IASPT index. This decline was slightly higher in the reaches that were affected by the massive growth of D. geminata; however, the declines in the various indices were not very apparent in any part of the stream. Therefore, our hypothesis 3 was partially validated because the changes observed in the biotic indices downstream of the reservoir were larger than the changes downstream of the wastewater inputs. In both cases, however, the changes were slight, and the ecological status of the streams was always "good" or "high", indicating that no significant changes were found in the biotic conditions of 
the streams. The IASPT index indicates the mean water quality tolerance of the macroinvertebrate taxa existing in a given stretch of the river (Armitage et al., 1983). In this study IASPT did not show a decline in the samples from the studied streams that were affected by the dam or by the massive growth of $D$. geminata. Although the stream reaches located downstream of the Pajares Reservoir and those affected by the massive growth of $D$. geminata experienced physical alterations (according to IHF index), together with a temperature modification in the first case, there were no important changes in the chemical characteristics of the water in these areas (the oxygen content did not change, and the nutrient content was not very high, even downstream of the sewage inputs). Because the IASPT and IBMWP indices are more sensitive to organic matter inputs than to physical factors, the lack of a relationship between the disturbances in these headwater systems and the biotic indices used is understandable. The IASPT represents an important percentage of the multimetric indices used in Mediterranean streams, especially the IMMi-L (Munné \& Prat, 2009), so the decline of the multimetric indices was not very large and the ecological status never declined below "good" (Munné \& Prat, 2009). Therefore, the ecological status results remained in the range required by the DMA to classify the streams as having "good" status (i.e., no restoration measures are required).

Considering these results, we can conclude that the various biotic indices used were not able to fully reflect the changes in the communities observed downstream of the Pajares Reservoir. This finding implies that an evaluation of the stream headwaters affected by physical pressures using biotic indices may produce false negative results (indicating no alteration when an alteration exists), giving the impression that no restoration measures are needed. However, a more detailed study of the community that used multivariate approaches indicated that the presence of the Pajares Reservoir resulted in an important disturbance in the Lumbreras Stream, causing several kilometers of this stream to be dominated by an invasive alga, which caused an important alteration of the macroinvertebrate community. Such alterations of the ecosystem should be studied and restored if possible. In the case of the Pajares Reservoir, we hypothesize that a change in the level of the water released from the reservoir (from the hypolimnion to the epilimnion) may produce important changes, especially in the growth of $D$. geminata. If the biomass of this alga was diminished and the water temperature was more similar to the upstream conditions, there would be less of a change in the community composition, though the stream flow would still significantly change.

\section{CONCLUSION}

In conclusion, the streams of Sierra Cebollera Natural Park are subjected to considerable anthropogenic pressures, especially the presence of the Pajares Reservoir. The macroinvertebrate community of stream reaches located downstream of this reservoir were clearly altered. This alteration primarily correlated with the massive growth of the invasive alga $D$. geminata downstream of the reservoir. However, the biotic indices did not reflect a significant deterioration of the ecological state of the ecosystem because the disturbances generated by the dam were physical and did not affect the water quality. It was also noted a certain alteration in the community in the stream reaches located downstream of the sewage discharges, especially in the Iregua Stream downstream of Villoslada de Cameros. However, this alteration was less important than that observed downstream of the dam due to the small magnitude of the sewage discharges, and the ecological status of the streams remained in the "high" category downstream of the wastewater discharges, according to the biotic indices.

\section{ACKNOWLEDGEMENTS}

The authors acknowledge all members of the FEM research group (Freshwater Ecology and Management) of the University of Barcelona for their valuable help with different aspects of the 
present work, particularly Joan Gomà and Pau Fortuño. We thank Bosco Imbert for his support with the field work. We also thank Associate Editor José Barquín and the two anonymous referees for their constructive comments on a previous version of this paper.

\section{REFERENCES}

AKAIKE, H. 1973. Information theory and an extension of the maximum likelihood principle. In: Second International Symposium on Information Theory. B.N. Petrov and F. Csake (eds.): 267-281. Aka,demiaiKiado, Budapest.

ALBA-TERCEDOR, J., P. JÁIMEZ-CUÉLLAR, M. ÁLVAREZ, J. AVILÉS, N. BONADA, J. CASAS, A. MELLADO, M. ORTEGA, I. PARDO, N. PRAT, M. RIERADEVALL, S. ROBLES, C. SÁINZ-CANTERO, A. SÁNCHEZ ORTEGA, M. SUÁREZ, M. TORO, M. VIDAL-ABARCA, S. VIVAS \& C. ZAMORA-MUÑOZ. 2002. Caracterización del estado ecológico de ríos mediterráneos ibéricos mediante el índice IBMWP (antes BMWP'). Limnetica, 21 (3-4): 175-185.

ASTM. 1995. Standard Methods for the Examination of Water and Wastewater 19th ed. American Public Health Association, American Water Works Association, and Water Environment Federation (APHA, AWWA, and WEF), Washington DC.

ANDERSON, M. J., R. N. GORLEY \& K. R. CLARKE. 2008. PRIMER + for PERMANOVA: Guide to Software and Statistical Methods. PRIMER-E. Ltd. Plymouth. United Kingdom.

ARMITAGE, P. D., D. MOSS, J. F. WRIGHT \& M. T. FLURSE. 1983. The performance of a new biological water quality score system based on macroinvertebrates over a wide range of unpolluted running-water sites. Water Research, 17 (3): 333-347.

ARNEKLEIV, J. V. 1985. Seasonal variability in diversity and species richness of ephemeropteran and plecopteran communities in a boreal stream. Fauna Norvegica, 32 (1): 1-6.

BLANCO, S. \& L. ECTOR. 2009. Distribution, ecology and nuisance effects of the freshwater invasive diatom Didymosphenia geminata (Lyngbye) M. Schmidt: a literature review. Nova Hedwigia, 3 (4): 347-422.

BIRK, S., W. BONNE, A. BORJA, S. BRUCET, A. COURRAT, S. POIKANE, A. SOLIMINI, W.
VAN DE BUND, N. ZAMPOUKAS \& D. HERING. 2012. Three hundred ways to assess Europe's surface waters: An almost complete overview of biological methods to implement the Water Framework Directive. Ecological Indicators, 18: $31-41$.

BONADA, N., N. PRAT, V. H. RESH \& B. STATZNER. 2006. Developments in aquatic insect biomonitoring: a comparative analysis of recent approaches. Annual Review of Entomology, 51: 495-523.

BRUNO, M. C., B. MAIOLINI, M. CAROLLI \& L. SILVERI. 2010. Short time-scale impacts of hydropeaking on benthic invertebrates in an Alpine stream (Trentino, Italy). Limnologica, 40 (4): 281 290.

BUNN, S. E. \& A. H. ARTHINGTON. 2002. Basic Principles and Ecological Consequences of $\mathrm{Al}-$ tered Flow Regimes for Aquatic Biodiversity. Environmental Management, 30 (4): 492-507.

CASTILLO, L. E., E. MARTÍNEZ, C. RUEPERT, C. SAVAGE, M. GILEK, M. PINNOCK \& E. SOLIS. 2006. Water quality and macroinvertebrate community response following pesticide applications in a banana plantation, Limon, Costa Rica. The Science of the Total Environment, 367 (1): 418-32.

CLARKE, K. R. 1993. Non-parametric multivariate analyses of changes in community structure. Australian Journal of Ecology, 18 (1): 117-143.

DUFRÊNE, M. \& P. LEGENDRE. 1997. Species assemblages and indicator species: the need for a flexible asymmetrical approach. Ecological Monographs, 67 (3): 345-366.

DYER, S. D., C. PENG, D. C. MCAVOY, N. J. FENDINGER, P. MASSCHELEYN, L. V. CASTILLO \& J. M. U. LIM. 2003. The influence of untreated wastewater to aquatic communities in the Balatuin River, The Philippines. Chemosphere, 52 (1): 43-53.

ECTOR, L. \& F. RIMET. 2005. Using bioindicators to assess rivers in Europe: An overview. In: Modelling community structure in freshwater ecosystems. S. Lek, M. Scardi, P. F. M. Verdonschot, J. P. Descy \& Y. S. Park (eds.): 7-19. Springer, Berlin, Germany.

ELLWOOD, N. T. W. \& B. A. WHITTON. 2007. Importance of organic phosphate hydrolyzed in stalks of the lotic diatom Didymosphenia geminata and the possible impact of atmospheric and climatic changes. Hydrobiologia, 592 (1): 121-133. 
GERHARDT, A., L. JANSSENS DE BISTHOVEN \& A. SOARES. 2004. Macroinvertebrate response to acid mine drainage: community metrics and online behavioural toxicity bioassay. Environmental Pollution, 130 (2): 263-274.

GILLIS, C. A. \& M. CHALIFOUR. 2010. Changes in the macrobenthic community structure following the introduction of the invasive algae Didymosphenia geminata in the Matapedia River (Québec, Canada). Hydrobiologia, 647 (1): 63-70.

GRANTHAM, T. E., M. CAÑEDO-ARGÜELLES, I. PERRÉE, M. RIERADEVALL \& N. PRAT. 2012. A mesocosm approach for detecting stream invertebrate community responses to treated wastewater effluent. Environmental Pollution, 160: 95-102.

GÜCKER, B., M. BRAUNS \& M. T. PUSCH. 2006. Effects of wastewater treatment plant discharge on ecosystem structure and function of lowland streams. Journal of the North American Benthological Society, 25 (2): 313-329.

GULIS, V. \& K. SUBERKROPP. 2003. Leaf litter decomposition and microbial activity in nutrient enriched and unaltered reaches of a headwater stream. FreshwaterBiology, 48: 123-134.

HEISKANEN, A. S., W. VAN DE BUND, A. C. CARDOSO \& P. NOGES. 2004. Towards good ecological status of surface waters in EuropeInterpretation and harmonisation of the concept. Water Science \& Technology, 49 (7): 169-177.

HORSÁK, M., J. BOJKOVÁ, S. ZAHRÁDKOVÁ, M. OMESOVÁ \& J. HELEŠIC. 2009. Impact of reservoirs and channelization on lowland river macroinvertebrates: A case study from Central Europe. Limnologica - Ecology and Management of Inland Waters, 39 (2): 140-151.

HRODEY, P. J., B. J. KALB \& T. M. SUTTON. 2008. Macroinvertebrate community response to large-woody debris additions in small warmwater streams. Hydrobiologia, 605 (1): 193-207.

JAKOB, C., C. T. ROBINSON \& U. UEHLINGER. 2003. Longitudinal effects of experimental floods on stream benthos downstream from a large dam. Aquatic Sciences-Research Across Boundaries, 65 (3): 223-231.

JÁIMEZ-CUÉLLAR, P., S. VIVAS, N. BONADA, S. ROBLES, A. MELLADO, M. ÁllarEZ, J. AVILÉS, J. CASAS, M. ORTEGA, I. PARDO, N. PRAT, M. RIERADEVALL, C. E. SÁINZCANTERO, A. SÁNCHEZ-ORTEGA, M. SUÁREZ, M. TORO, M. VIDAL-ABARCA, C. ZAMORA-MUÑOZ \& J. ALBA-TERCEDOR.
2002. Protocolo Guadalmed (PRECE). Limnetica, 21 (3-4): 187-204.

KILROY, C. \& M. L. BOTHWELL. 2012. Didymosphenia geminata growth rates and bloom formation in relation to ambient dissolved phosphorus concentration. Freshwater Biology, 57 (4): 641653.

KILROY, C., S. T. LARNED \& B. J. F. BIGGS. 2009. The non-indigenous diatom Didymosphenia geminata alters benthic communities in New Zealand rivers. Freshwater Biology, 54 (9): 1990-2002.

KIRKWOOD, A. E., L. J. JACKSON \& E. MCCAULEY. 2009. Are dams hotspots for Didymosphenia geminata blooms? Freshwater Biology, 54 (9): 1856-1863.

KIRKWOOD, A. E., T. SHEA, L. J. JACKSON \& E. MCCAULEY. 2007. Didymosphenia geminata in two Alberta headwater rivers: an emerging invasive species that challenges conventional views on algal bloom development. Canadian Journal of Fisheries and Aquatic Sciences, 64 (12): 17031709.

KUMAR, S., S. A. SPAULDING, T. J. STOHLGREN, K. A. HERMANN, T. S. SCHMIDT \& L. L. BAHLS. 2009. Potential habitat distribution for the freshwater diatom Didymosphenia geminata in the continental US. Frontiers in Ecology and the Environment, 7: 415-420.

LARSON, A. M. 2007. Relationships between nuisance blooms of Didymosphenia geminata and measures of aquatic community composition in Rapid Creek, South Dakota (Technical report). South Dakota Department of Environment and Natural Resources. USA.

LYTLE, D. A. \& N. L. POFF. 2004. Adaptation to natural flow regimes. Trends in Ecology \& Evolution, 19 (2): 94-100.

MMARM. 2008. ORDEN ARM/2656/2008, de 10 de septiembre, por la que se aprueba la Instrucción de Planificación Hidrológica. Ministerio de Medio Ambiente y Medio Rural y Marino.

MÉRIGOUX, S. \& S. DOLÉDEC. 2004. Hydraulic requirements of stream communities?: a case study on invertebrates. Freshwater Biology, 49 (5): 600613.

MILLER, M. P., D. M. MCKNIGHT, J. D. CULLIS, A. GREENE, K. VIETTI \& D. LIPTZIN. 2009. Factors controlling streambed coverage of Didymosphenia geminata in two regulated streams in the Colorado Front Range. Hydrobiologia, 630 (1): 207-218. 
MUNN, M. D. \& M. A. BRUSVEN.1991. Benthic macroinvertebrate communities in nonregulated and regulated waters of the Clearwater River, Idaho, USA. Regulated Rivers: Research \& Management, 6 (1): 1-11.

MUNNÉ, A. 2009. Análisis de métriques d'avaluació de la qualitat de l'aigua mitjançant l'us de macroinvertebrats com a bioindicadors y la seva resposta a les alteracions antrópiques $i$ a la tipologia fluvial en ecosistemes mediterranis. Tesis Doctoral. Universitat de Barcelona.

MUNNÉ, A. \& N. PRAT. 2009. Use of macroinvertebrate-based multimetric indices for water quality evaluation in Spanish Mediterranean rivers: an intercalibration approach with the IBMWP index. Hydrobiologia, 628 (1): 203-225.

MUNNÉ, A., N. PRAT, C. SOLÁ, N. BONADA \& M. RIERADEVALL. 2003. A simple field method for assessing the ecological quality of riparian habitat in rivers and streams: QBR index. Aquatic Conservation: Marine and Freshwater Ecosystems, 13 (2): 147-163.

NUÑEZ, M. \& N. PRAT. 2010. Efecto de la sequía y las crecidas en los índices biológicos en el río Llobregat. Tecnología del Agua, 320: 46-55.

OKSANEN, J., F. G. BLANCHET, R. KINDT, P. LEGENDRE, P. R. MINCHIN, R. B. O'HARA, G. L. SIMPSON, P. SOLYMOS, M. H. H. STEVENS, H. WAGNER. 2012. Vegan: Community Ecology Package. $R$ package version 2.0-3. R Foundation for Statistical Computing. Vienna, Austria. Available from: http://cran.r-project.org/ package $=$ vegan

ORDOCI, L. 1967. An agglomerative method for classification of plant communities. Journal of Ecology, 55: 193-206.

ORTIZ, J. D. \& M. A. PUIG. 2007. Point source effects on density, biomass and diversity of benthic macroinvertebrates in a Mediterranean stream. River Research and Applications, 23 (2): 155-170.

PARDO, I., M. ÁlVAREZ, J. CASAS, J. L. MORENO, S. VIVAS, N. BONADA, J. ALBATERCEDOR, P. JÁIMEZ-CUÉLLAR, G. MOYÀ, N. PRAT, S. ROBLES, M. SUÁREZ, M. TORO \& M. VIDAL-ABARCA. 2002. El hábitat de los ríos mediterráneos. Diseño de un índice de diversidad de hábitat. Limnetica, 21 (3-4): 115-133.

PERRY, S. A., W. B. PERRY \& J. A. STANFORD. 1986. Effects of stream regulation on density, growth, and emergence of two mayflies (Ephemeroptera: Ephemerellidae) and a caddisfly
(Trichoptera: Hydropsychidae) in two Rocky Mountain rivers (USA). Canadian Journal of Zoology, 64 (3): 656-666.

POFF, N. L. R., J. D. OLDEN, N. K. M. VIEIRA, D.S. FINN, M. P. SIMMONS \& B. C. KONDRATIEFF. 2006. Functional trait niches of North American lotic insects: traits-based ecological applications in light of phylogenetic relationships. Journal of the North American Benthological Society, 25 (4): 730-755.

POFF, N. L., B. D. RICHTER, A. H. ARTHINGTON, S. E. BUNN, R. J. NAIMAN, E. KENDY, M. ACREMAN, C. APSE, B. P. BLEDSOE, M. C. FREEMAN, J. HENRIKSEN, R. B. JACOBSON, J. G. KENNEN, D. M. MERRITT, J. H. O'KEEFFE, J. D. OLDEN, K. ROGERS, R. E. THARME \& A. WARNER. 2010. The ecological limits of hydrologic alteration (ELOHA): a new framework for developing regional environmental flow standards. Freshwater Biology, 55 (1): 147170.

PRAT, N. 1981. The influence of reservoirs discharge of benthic fauna in the river Ter, NE Spain. Series Entomologica, 20: 293-301.

PUIG, M. A. 1999. Els macroinvertebrats dels rius catalans. Departament de Medi Ambient. Generalitat de Catalunya.

RICHTER, B. D., A. T. WARNER, J. L MEYER \& K. LUTZ. 2006. A collaborative and adaptive process for developing environmental flow recommendations. River Research and Applications, 22 (3): 297-318.

RIERADEVALL, M., N. BONADA \& N. PRAT. 1999. Community structure and water quality in the Mediterranean streams of a natural park (St. Llorenç del Munt, NE Spain). Limnetica, 17: 45-56.

RUEDA, J., A. CAMACHO, F. MEZQUITA, R. HERNÁNDEZ \& J. R. ROCA. 2002. Effect of episodic and regular sewage discharges on the water chemistry and macroinvertebrate fauna of a Mediterranean stream. Water, Air, \& Soil Pollution, 140 (1): 425-444.

SHAFROTH, P. B., A. C. WILCOX, D. LYTLE, J. T. HICKEY, D. C. ANDERSEN, V. B. BEAUCHAMP, A. HAUTZINGER, L. E. MCMULLEN \& A. WARNER. 2010. Ecosystem effects of environmental flows: modelling and experimental floods in a dryland river. Freshwater Biology, 55 (1): 68-85. 
SOKAL, R. R. \& F. J. ROHLF. 1981. Biometry: the principles and practice of statistics in biological research. W. H. Freeman. New York. USA.

SPÄNHOFF, B., R. BISCHOF, A. BÖHME, S. LORENZ, K. NEUMEISTER, A. NÖTHLICH \& K. KÜSEL. 2007. Assessing the impact of effluents from a modern wastewater treatment plant on breakdown of coarse particulate organic matter and benthic macroinvertebrates in a lowland river. Water, Air, \& Soil Pollution, 180 (1): 119-129.

SVENSSON, B. S. 2001. Growth of macroinvertebrates in regulated and free-flowing northern Swedish rivers. Verhandlungen Internationale Vereinigung für Theoretische und Angewandte Limnologie, 27, 1-5.

TACHET, H., P. RICHOUX, M. BOURNAUD \& P. USSEGLIO-POLATERRA. 2006. Invertébrés d'eau douce. Systématique, biologie, écologie.
CNRS Editions. Paris. France.

TER BRAAK, C. J. F. \& P. SMILAUER P. 2002. Canoco 4.5: Reference Manual and Canodraw for Windows. User's Guide: Software Form Canonical Community Ordination (version 4.5). Microcomputer Power. Ithaca. New York. USA.

VIVAS, S., J. CASAS, I. PARDO, S. ROBLES, N. BONADA, A. MELLADO, N. PRAT, J. ALBATERCEDOR, M. ÁLVAREZ \& M. M. BAYO. 2002. Aproximación multivariante en la exploración de la tolerancia ambiental de las familias de macroinvertebrados de los ríos mediterráneos del proyecto GUADALMED. Limnetica, 21, 149-173.

WARD, J. V. \& J. A. STANFORD. 1982. Thermal responses in the evolutionary ecology of aquatic insects. Annual Review of Entomology, 27 (1): 97117. 
